\title{
How to Protect Ovarian Function before and during Chemotherapy?
}

\author{
Luca Arecco $^{1,2}$ D, Tommaso Ruelle ${ }^{2,3}$, Valentino Martelli ${ }^{2,4} \mathbb{D}^{\mathbb{D}}$, Andrea Boutros ${ }^{2,3}$, Maria Maddalena Latocca ${ }^{1,2} \mathbb{D}$, \\ Stefano Spinaci ${ }^{5}$, Camilla Marrocco ${ }^{1}$ (D), Claudia Massarotti ${ }^{6,7}$ (D) and Matteo Lambertini ${ }^{1,2, *(D)}$
}

1 U.O. Clinica di Oncologia Medica, IRCCS Ospedale Policlinico San Martino, 16132 Genova, Italy; arecco.luca@gmail.com (L.A.); mariamaddalena.latocca@gmail.com (M.M.L.); camilla.marrocco@hotmail.com (C.M.)

2 Department of Internal Medicine and Medical Sciences (DiMI), School of Medicine, University of Genova, 16132 Genova, Italy; tommirue@gmail.com (T.R.); martellivalentino91@gmail.com (V.M.); boutros.andrea@gmail.com (A.B.)

3 U.O. Oncologia Medica 2, IRCCS Ospedale Policlinico San Martino, 16132 Genova, Italy

4 U.O. Oncologia Medica 1, IRCCS Ospedale Policlinico San Martino, 16132 Genova, Italy

5 Division of Breast Surgery, Ospedale Villa Scassi ASL3, 16149 Genova, Italy; stefano.spinaci@hotmail.com

6 Department of Neurosciences, Rehabilitation, Ophthalmology, Genetics, Maternal and Child Health (DiNOGMI), School of Medicine, University of Genova, 16132 Genova, Italy; claudia.massarotti@gmail.com

7 Academic Unit of Obstetrics and Gynaecology, IRCCS Ospedale Policlinico San Martino, 16132 Genova, Italy

* Correspondence: matteo.lambertini@unige.it; Tel.: +39-010-555-4254; Fax: +39-010-555-6536

check for updates

Citation: Arecco, L.; Ruelle, T.; Martelli, V.; Boutros, A.; Latocca, M.M.; Spinaci, S.; Marrocco, C.; Massarotti, C.; Lambertini, M. How to Protect Ovarian Function before and during Chemotherapy? J. Clin. Med. 2021, 10, 4192. https://doi.org/ $10.3390 / \mathrm{jcm} 10184192$

Academic Editors: Jacques Donnez and Enrico Carmina

Received: 9 August 2021

Accepted: 3 September 2021

Published: 16 September 2021

Publisher's Note: MDPI stays neutral with regard to jurisdictional claims in published maps and institutional affiliations.

Copyright: (c) 2021 by the authors. Licensee MDPI, Basel, Switzerland. This article is an open access article distributed under the terms and conditions of the Creative Commons Attribution (CC BY) license (https:// creativecommons.org/licenses/by/ $4.0 /)$.

\begin{abstract}
A significant number of women receive a cancer diagnosis before their age of natural menopause. Among these patients, the most frequent neoplasms are breast cancer, gynecological, and hematological malignancies. Premature ovarian insufficiency and infertility are among the most feared short- to long-term consequences of anticancer treatments in premenopausal patients. Both patient- and treatment-related characteristics are key factors in influencing the risk of gonadotoxicity with the use of chemotherapy. The cryopreservation of oocytes/embryos is a standard strategy for fertility preservations offered to young women interested in future family planning, but it does not allow gonadal function protection during chemotherapy. Ovarian suppression with gonadotropinreleasing hormone agonist $(\mathrm{GnRHa})$ during chemotherapy is now recommended as an option to reduce the risk of gonadotoxicity in order to avoid the negative consequences of premature ovarian insufficiency in premenopausal women receiving cytotoxic therapy, including those not interested in fertility preservation. This review summarizes the risk of treatment-induced gonadotoxicity in premenopausal patients and the evidence available on the protective role of administering GnRHa during chemotherapy to preserve ovarian function.
\end{abstract}

Keywords: cancer; premenopausal patients; ovarian function preservation; premature ovarian insufficiency

\section{Introduction}

Thanks to improvements in cancer prognosis, increased attention should be paid to the future quality of life for patients exposed to anticancer treatments [1]. The risk of treatment-induced gonadotoxicity is among the most feared short- and long-term time side effects of anticancer therapies in premenopausal women [2]. Developing premature ovarian insufficiency (POI) and infertility are of high concern to many patients [3]. Therefore, trying to reduce the impact of these side effects is of primary importance [4]. The most frequent neoplasms diagnosed in premenopausal women and associated with the risk of developing these side effects are breast, gynecological and hematological malignancies [5].

As recommended by current guidelines, proper oncofertility counseling is recommended in all premenopausal women irrespective of the type of their disease and stage $[1,6]$. 
During counseling, patients should be informed about the risk of developing POI with the proposed treatment and the available strategies to counteract this side effect. The difference between fertility and ovarian function preservation should be explained, as well as the different eligibility criteria needed to access the available strategies.

The cryopreservation of oocytes/embryos and/or ovarian tissue are standard strategies for fertility preservation in young women who are interested in future family planning [1,6]. These strategies should be offered preferably to young women with a suggested age cut-off of 40 and 36 years for oocyte/embryo and ovarian tissue cryopreservation, respectively [1]. While ovarian function recovery is possible after ovarian tissue cryopreservation, cryopreserving oocytes/embryos does not protect against the risk of treatment-induced POI. For ovarian function preservation, the only recommended medical treatment is the administration of gonadotropin-releasing hormone agonist (GnRHa) during chemotherapy $[1,6]$. This strategy has been developed as an option to reduce the risk of gonadotoxicity in order to avoid the negative consequences of POI in premenopausal women (including patients older than 40 years at diagnosis) receiving cytotoxic therapy [7]. Hence, this is a strategy that can be offered also to patients who are not interested in fertility preservation.

As recently shown in the prospective PREFER study, while less than $20 \%$ of young women diagnosed with breast cancer before the age of 40 years decided to undergo cryopreservation strategies for fertility preservation, more than $90 \%$ of them accepted the use of GnRHa during chemotherapy [8]. Moreover, $90.6 \%$ of patients aged $41-45$ years at diagnosis (i.e., those normally not candidates to fertility preservation strategies) decided to receive GnRHa during chemotherapy to reduce the risk of POI and its consequences [8]. The impact of estrogen deficiency due to an early loss of ovarian function on the quality of life and general health of these patients in the long-term should not be undervalued [9]. Therefore, it is important for clinicians involved in cancer care to properly discuss POI risk as well as the importance of ovarian function preservation.

This review summarizes the risk of treatment-induced gonadotoxicity in premenopausal patients and the available evidence on the protective role of administering GnRHa during chemotherapy to preserve ovarian function.

\section{Risk of Chemotherapy-Induced Ovarian Damage}

\subsection{Cytotoxic Agents}

To estimate the risk of treatment-induced gonadotoxicity, both patient- and treatmentrelated factors should be considered during counseling [1,6]. Regarding the patient, the most important factor to influence this risk is represented by the age at the time of treatment: the same treatment is associated with higher POI risk the older the age of the patient (i.e., the closer the woman is to her natural age at menopause) $[1,6]$. Genetic factors may also play a role. Germline pathogenic variants in BRCA genes have shown to be potentially associated with a reduced ovarian reserve at diagnosis [10]. However, limited and conflicting data are available on their role in influencing the risk of treatment-induced gonadotoxicity [11-13].

In terms of treatment-related factors, the type and dose of chemotherapy have a major impact on the risk of gonadotoxicity $[1,6]$.

In general, different mechanisms are associated with the ovarian toxicity of chemotherapy. The germ cells pool can be damaged through a direct effect on double-strand DNA or acceleration in follicular activation [14], but also with an indirect impact on the stroma in terms of decrease of blood vessels and reduction of blood supply [15].

Alkylating agents, such as cyclophosphamide, are widely used for the treatment of many malignancies. These are the agents associated with the highest gonadotoxic impact [16]. A metanalysis by Zhao et al. demonstrated that cyclophosphamide-based regimens can lead to a higher incidence of amenorrhea compared to the cyclophosphamidefree ones (OR 2.25; 95\% CI 1.26-4.03, $p=0.006$ ) [17]. The impact of different chemotherapy regimens, also according to the patients' age at the time of treatment, has been recently summarized in international guidelines $[1,6]$. 


\subsection{Monoclonal Antibodies}

Monoclonal antibodies are now routinely administered in clinical practice in different malignancies. Doubts remain about their actual gonadotoxicity, as they are often combined with other chemotherapeutic drugs. Limited data exist on the possible effects on ovarian function and fertility of anti-HER2 therapies.

The ALTTO trial suggested the gonadal safety of trastuzumab and/or lapatinib [18]. The rate of amenorrhea was $72.6 \%$ with trastuzumab alone, $74.0 \%$ with lapatinib alone, and $74.8 \%$ and $72.1 \%$ with combination and sequential use, respectively $(p=0.64)$. However, all patients received prior chemotherapy and there was no control arm without anti-HER2 agents [18].

Other data about the gonadotoxicity of trastuzumab derive from the APT trial. Ruddy et al. evaluated the incidence of menstrual impairment in the premenopausal subgroup population receiving weekly paclitaxel with trastuzumab for 3 months, followed by trastuzumab monotherapy for completing one year of anti-HER2 therapy [18]. A lower rate of premature ovarian insufficiency $(28 \%)$ was shown with this treatment as compared to what is expected with other breast cancer adjuvant chemotherapy regimens [18].

\subsection{PARP Inhibitors}

The poly (ADP-ribose) polymerase (PARP) inhibitors are administered in patients harboring germline pathogenic variants in BRCA1/2. They are frequently employed in patients affected by breast or gynecological cancers, which account for a large proportion of premenopausal patients. There is some evidence about their effects on the gonads, even if extracted from mouse models [19]. Winship et al. assessed the activity of cyclophosphamide, doxorubicin and other anticancer drugs alone, or in combination with olaparib in BRCA wild-type murine ovarian cells. The primordial follicles have been found as the most affected by the combined regimen and in particular it has been observed the depletion of more than a third of their pool $(p<0.05)$ [19]. These agents may be soon available in the early setting; hence, it is imperative to highlights the need to investigate their gonadotoxicity in the clinical scenario.

\section{De-Escalation of Gonadotoxic Chemotherapy}

In recent years, alongside with increased therapeutic options in the treatment of early-stage cancer, a growing attention has been paid to tailoring the type and intensity of systemic therapies, while balancing between the individual risk of relapse and the toxicity caused by these therapies [20-23]. This concept of de-escalation of treatment applies also to finding alternative regimens with a reduced gonadotoxicity in premenopausal patients.

Breast cancer represents a clear example. The approach of reducing the number and the length of anticancer therapies has been investigated in depth in patients with HER2-positive breast cancer, thanks to the growing availability of very effective anti-HER2 agents [20-22]. As an example, the APT trial is a study that recruited 406 patients with node-negative $\mathrm{pT}$ $<3 \mathrm{~cm}$ HER2-positive breast cancer who underwent upfront surgery [21]. These patients received an anthracycline- and cyclophosphamide-free adjuvant regimen with weekly paclitaxel and trastuzumab followed by trastuzumab alone. After a median follow-up of 6.5 years, invasive disease-free survival (iDFS) rate was 93\% with a 7-years overall survival (OS) of $95 \%$, demonstrating the excellent prognosis of these patients, even when omitting anthracycline and cyclophosphamide from standard chemotherapy [21]. This is highly relevant for avoiding the toxicities of the anthracycline and cyclophosphamide chemotherapy component, which include the risk of gonadotoxicity in premenopausal women. In this trial, data on the chemotherapy-induced menorrhea were reported [24]. In this analysis, menstrual resumption after cytotoxic treatment was assessed with surveys sent every 6 months to patients during the first 3 years, and then every year for the whole duration of follow-up. Out the 406 patients recruited in the APT trial, 64 were eligible for this analysis being younger than 55 years, at least reporting one menstrual episode in the previous 6 months with a frequency of at least every 2 months (i.e., pre-menopausal 
status at baseline). Out of the 64 included patients, 18 (28\%) were amenorrheic and 46 $(72 \%)$ had not experienced amenorrhea at the time of the last menstrual survey, with a significant lower rate of chemotherapy-induced amenorrhea as compared to what was expected with standard adjuvant cytotoxic breast cancer regimens that also include an anthracycline and cyclophosphamide. As expected, the median age at study entry of patients who experienced chemotherapy-induced amenorrhea was higher than in patients with menstrual resumption ( 42 vs. 49 years), reinforcing the evidence that older age is a major risk factor for developing chemotherapy-induced amenorrhea [24].

In the same setting of HER2-positive early breast cancer, another attempt to de-escalate adjuvant chemotherapy in stage I disease is the ATEMPT trial [22]. This study evaluated the efficacy and safety of a one-year of treatment with single-agent trastuzumab emtansine (T-DM1), an antibody-drug conjugate [25], as compared to paclitaxel and trastuzumab [22]. A total of 497 patients were randomly assigned to T-DM1 or paclitaxel with trastuzumab. Out of the 383 patients randomized to T-DM1, 3-year iDFS was $97.8 \%$, with similar results as those observed in the APT trial (98.7\%) [22]. Notably, although the percentage of patients who experienced clinically relevant toxicities was almost equal (46\% T-DM1 vs. 47\% paclitaxel and trastuzumab, $p=0.83$ ), a higher rate of toxicity-related treatment discontinuation was observed in patients in the T-DM1 arm (17\% vs. 6\%). Patient-reported outcomes indicated that patients treated with T-DM1 had a better quality of life compared to those treated with paclitaxel and trastuzumab. The authors investigated the rate of amenorrhea among premenopausal patients recruited in the ATEMPT trial. In this analysis, 18-month chemotherapy-induced amenorrhea (defined as the absence of menses resumption in the previous 6 months) after therapy completion was the primary endpoint [26]. Out of the 383 patients randomized, 123 were premenopausal but only 76 patients (18 in the paclitaxel and trastuzumab arm and 58 in the T-DM1 arm) had menopausal data available at 18 months. The rate of chemotherapy-induced amenorrhea was 50\% in the trastuzumab and paclitaxel group and $24 \%$ in the T-DM1 group $(p=0.045)$. These rates seemed to increase in the T-DM1 arm after 18 months compared to paclitaxel and trastuzumab, perhaps because a longer duration of T-DM1 administration (12 months versus 3 months of paclitaxel and trastuzumab) can cause a delayed chemotherapy-induced amenorrhea. Although there is a trend towards a reduction in gonadotoxicity compared to standard chemotherapy, future studies are warranted to fully investigate the gonadotoxicity of T-DM1.

An additional example in the HER2-positive setting, but in patients at higher risk of disease recurrence and receiving neoadjuvant treatment, is represented by the TRAIN-2 study that investigated the possibility to reduce the chemotherapy burden by implementing the anti-HER2 blockade [20]. The TRAIN-2 study is a randomized phase III trial in which 438 patients with stage II/III were randomized to receive dual HER2 blockade with pertuzumab and trastuzumab in association with carboplatin and paclitaxel or 5fluorouracil, epirubicin, and cyclophosphamide, followed by paclitaxel and carboplatin. An equivalent percentage of pathological complete responses (pCR) was observed in both groups (68\% in the anthracycline-free group vs. $67 \%$ in the anthracycline group), with a significant reduction in serious adverse events (SAE) in the anthracycline-free group (22\% vs. $28 \%$ ). From the recent three-year follow-up analysis, event-free survival (EFS) estimates were $92.7 \%$ in the anthracycline group and $93.6 \%$ in the anthracycline-free group, while 3-year OS were $97.7 \%$ in the anthracycline group and $98.2 \%$ in the anthracycline-free group, showing a similar estimated EFS and OS associated with decreased risk of febrile neutropenia, cardiotoxic effects, and secondary malignant neoplasms in the anthracycline-free group [27].

Sparing the gonadotoxicity of anthracyclines and cyclophosphamide in premenopausal women would be of great importance and is the standard of care in low risk HER2-positive breast cancer [28], but further studies are needed to refine the selection of patients with other tumor subtypes or with HER2-positive disease but at higher risk of recurrence that can be candidates to such de-escalated approach. 
A recent study in women with HER2-negative/estrogen receptor-positive early breast cancer investigated a de-escalated chemotherapy approach with the main aim of reducing its gonadotoxicity by removing the cyclophosphamide component without compromising its prognosis. This phase III trial randomized 521 breast cancer patients aged $<40$ after upfront surgery to receive standard chemotherapy with epirubicin and cyclophosphamide, followed by weekly paclitaxel (EC-wP) or a cyclophosphamide-free regimen (epirubicin and paclitaxel, which was then followed by weekly paclitaxel [EP-wP]) [23]. The coprimary endpoints were 5-years iDFS and rate of menstrual resumption at 12 months after chemotherapy, defined as two consecutive menstruations, or only one menstruation with pre-menopausal levels of estradiol and follicle-stimulating hormone. After a median follow-up of 62 months, 5-years iDFS was $84.7 \%$ in the EP-wP arm (95\% CI 79.3\% to $88.8 \%$ ) and $78.3 \%$ in the EC-wP arm (95\% CI $72.2 \%$ to $83.3 \%$ ). When considering the other co-primary endpoint, a significantly higher rate of menstrual resumption was observed in patients treated without cyclophosphamide $(63.1 \%$ in EP-wP vs. $48.3 \%$ in EC-wP, $95 \%$ CI $42.2 \%$ to $54.3 \%$ ) with an absolute difference of $14.8 \%$ (95\% CI $6.37 \%$ to $23.2 \%, p<0.001$ ). In the post hoc exploratory analysis of pregnancy outcomes, of the 228 patients analyzed, successful pregnancy occurred in $2.7 \%$ women in the EC-wP group and $9.6 \%$ in the EP-wP group $(p=0.03)[23]$.

\section{Ovarian Suppression with GnRHa during Chemotherapy}

In order to prevent chemotherapy-induced POI and early menopause-related symptoms, the administration of GnRHa during chemotherapy is to date the only medical strategy available for clinical use $[1,6,29]$. To date, the mechanisms underlying the protective role of ovarian suppression with GnRHa during chemotherapy have not been fully understood [30]; this is the main reason for the long debate around the role of this strategy [31]. However, several randomized trials have clarified its efficacy and safety, particularly in premenopausal women with early breast cancer.

\subsection{Mechanisms of Action}

After the pubertal age, most of the follicles are quiescent at the primordial stage; after reaching prenatal stage, follicle development depends on the secretion of gonadotropins (follicles-stimulating hormone $[\mathrm{FSH}]$ and luteinizing hormone $[\mathrm{LH}]$ ), regulated by the secretion of GnRH by the hypothalamus [7]. Chemotherapy-induced gonadotoxicity involves all follicular stages and cell types, impairing both ovarian reserve and hormonal function through direct and indirect damages [32]. To date, the mechanism underlying the protective gonadal effect of GnRHa is not fully clear, but this strategy seems to have both indirect and direct effects on the ovaries.

\subsubsection{Indirect Effects}

The protective action of GnRHa was initially attributed to the reaching of a prepubertal hormonal state [7]. The administration of GnRHa induces an initial release of gonadotropin, which causes a desensitization of GnRH-receptors and prevents from the effects of pulsatile GnRH secretion (the "flare-up effect") [33]. This condition would be able to generate a hypogonadotropic state that keeps the follicles in a quiescent state, making them less vulnerable to chemo-induced damage [34]. Cytotoxic agents cause the apoptosis of follicles, decreasing the levels of estrogens and inhibin and, accordingly, increased the levels of FSH, which stimulates the recruitment of primordial follicles (the so called "burn-out effect of chemotherapy"). Therefore, the GnRH-induced FSH suppression slows down the proliferation of follicular cells, protecting them from the cytotoxic damage and delaying the recruitment of the follicular pool of quiescent cells [33].

In addition, proliferating follicles also release anti-müllerian hormone (AMH), which can negatively regulate the primordial follicles recruiting. During chemotherapy, AMH levels are usually dramatically lowered, causing a recruitment of primordial follicles and 
exposing them to chemo-induced damage. It has been observed that the addition of GnRHa can raise AMH levels and prevent this effect [35,36].

Finally, despite a limited number of data, another potential indirect protective mechanism of GnRHa is the reduction of utero-ovarian perfusion, which would also reduce the exposure of follicles to the gonadotoxic effect of treatments [29].

\subsubsection{Direct Effects}

It has been observed that GnRH receptors are expressed on the surface of the ovarian cells and that their activation may result in an anti-apoptotic effect; this effect is currently poorly understood $[37,38]$.

Furthermore, GnRHa may be involved in the upregulation of the anti-apoptotic molecule sphingosine-1-phosphate (S1P), which inhibits the ceramide pathway involved in chemo-induced apoptosis of the ovarian cells. Moreover, S1P improves neo-angiogenesis in primordial ovarian follicles, producing a potential further protective effect in the ovaries [39]. It has been observed that S1P has an anti-apoptotic effect on oocytes exposed in vivo and in vitro to chemotherapy $[40,41]$, but there is still no experimental evidence that GnRHa administration increases level of S1P or other anti-apoptotic molecules. It has also been found that germ line stem cells are present in the ovarian tissue, which are able to reconstitute the primordial follicle pool [42]. GnRHa administration may promote the activation of primordial follicles after the completion of chemotherapy, interacting with these germ cells $[43,44]$.

Recently, Scaruffi et al. evaluated the effect of chemotherapy (i.e., cyclophosphamide) and GnRHa alone, or in combination with chemotherapy on a culture system of ex vivo human immature cumulus cell-oocyte complexes. The effects of these treatments were evaluated on GnRH receptors, ceramide, and apoptosis pathways and glutathione synthesis. This study demonstrated that cyclophosphamide was mainly detrimental to the cumulus cells compartment through the activation of apoptosis molecular signals. Furthermore, it was found that GnRHa co-administration downregulated the expression of some proapoptotic genes and up-regulated transcription of the anti-apoptotic gene only in cumulus cells with an indirect protective effect on oocytes [45]. These results are in contrast with previous data that excluded a protective effect of GnRHa against cyclophosphamide in ex vivo and in vitro models of human ovary and granulosa cells [46]. The authors suggested that this difference may be due both to the different timing of drug administration and to the different dose of GnRHa used for experiments. In fact, in the work by Scaruffi et al. GnRHs was administered earlier before the addition of chemotherapy and with a higher dose than in the model of Bildik and colleagues.

\subsection{Clinical Data in Breast Cancer}

Most of the evidence supporting the use of GnRHa in the prevention of chemotherapyinduced POI exists in premenopausal women with early breast cancer [47]. A total of 15 randomized trials have been conducted in this setting (Table 1) [48-64]. 
Table 1. Randomized trials evaluating temporary ovarian suppression with GnRHa during chemotherapy in breast cancer patients.

\begin{tabular}{|c|c|c|c|c|c|c|c|}
\hline Authors & Year & $\begin{array}{c}\text { POI } \\
\text { Definition } \\
\text { (Timing of Its } \\
\text { Evaluation) }\end{array}$ & $\begin{array}{l}\text { Timing POI } \\
\text { Evaluation } \\
\text { (Months) }\end{array}$ & $\begin{array}{l}\text { Treatment } \\
\text { Regimen }\end{array}$ & No. Patients & $\begin{array}{l}\text { Median Age } \\
\text { (Years) }\end{array}$ & $\begin{array}{l}\text { Overall } \\
\text { Results }\end{array}$ \\
\hline Li et al. [48] & 2008 & Amenorrhea & 12 & $\begin{array}{c}\mathrm{CT}+\text { goserelin } \\
\mathrm{CT} \text { alone }\end{array}$ & $\begin{array}{l}31 \\
32\end{array}$ & $\begin{array}{l}40 \\
39\end{array}$ & Protection \\
\hline $\begin{array}{l}\text { Badawy } \\
\text { et al. [49] }\end{array}$ & 2009 & $\begin{array}{l}\text { Amenorrhea } \\
\text { without } \\
\text { resumption of } \\
\text { ovulation }\end{array}$ & 8 & $\begin{array}{c}\mathrm{CT}+\text { goserelin } \\
\mathrm{CT} \text { alone }\end{array}$ & $\begin{array}{l}39 \\
39\end{array}$ & $\begin{array}{c}30 \\
29.2\end{array}$ & Protection \\
\hline $\begin{array}{l}\text { Sverrisdottir } \\
\text { et al. [50] }\end{array}$ & 2009 & Amenorrhea & Up to 36 & $\begin{array}{c}\text { CT + goserelin } \\
( \pm \text { tamoxifen }) \\
\text { CT }( \pm \text { tamoxifen })\end{array}$ & $\begin{array}{l}51 \\
43\end{array}$ & $\begin{array}{c}45 \\
45-46\end{array}$ & Protection \\
\hline Gerber et al. [51] & 2011 & Amenorrhea & 6 & $\begin{array}{c}\mathrm{CT}+\text { goserelin } \\
\mathrm{CT} \text { alone }\end{array}$ & $\begin{array}{l}30 \\
30\end{array}$ & $\begin{array}{c}35 \\
38.5\end{array}$ & $\begin{array}{l}\text { No } \\
\text { protection }\end{array}$ \\
\hline Sun et al. [52] & 2011 & Amenorrhea & 12 & $\begin{array}{c}\mathrm{CT}+\text { goserelin } \\
\mathrm{CT} \text { alone }\end{array}$ & $\begin{array}{l}11 \\
10\end{array}$ & $\begin{array}{l}38 \\
37\end{array}$ & Protection \\
\hline $\begin{array}{l}\text { Del Mastro } \\
\text { et al. [53] } \\
\text { Lambertini } \\
\text { et al. [58] } \\
\text { Lambertini } \\
\text { et al. [65] }\end{array}$ & $\begin{array}{l}2011 \\
2015 \\
2021\end{array}$ & $\begin{array}{l}\text { Amenorrhea } \\
\text { and post- } \\
\text { menopausal } \\
\text { levels of FSH } \\
\text { and E2 }\end{array}$ & 12 & $\begin{array}{c}\mathrm{CT}+\text { triptorelin } \\
\mathrm{CT} \text { alone }\end{array}$ & $\begin{array}{l}148 \\
133\end{array}$ & $\begin{array}{l}39 \\
39\end{array}$ & Protection \\
\hline $\begin{array}{l}\text { Munster } \\
\text { et al. [54] }\end{array}$ & 2012 & Amenorrhea & 24 & $\begin{array}{c}\mathrm{CT}+\text { triptorelin } \\
\mathrm{CT} \text { alone }\end{array}$ & $\begin{array}{l}27 \\
22\end{array}$ & $\begin{array}{l}39 \\
38\end{array}$ & $\begin{array}{l}\text { No } \\
\text { protection }\end{array}$ \\
\hline $\begin{array}{l}\text { Elgindy } \\
\text { et al. [59] }\end{array}$ & 2013 & Amenorrhea & 12 & $\begin{array}{c}\mathrm{CT}+\text { triptorelin } \\
( \pm \mathrm{GnRHa} \\
\text { antagonist }) \\
\text { CT alone }\end{array}$ & $\begin{array}{l}50 \\
50\end{array}$ & $\begin{array}{l}33 \\
32\end{array}$ & $\begin{array}{l}\text { No } \\
\text { protection }\end{array}$ \\
\hline Song et al. [55] & 2013 & $\begin{array}{l}\text { Amenorrhea } \\
\text { and post- } \\
\text { menopausal } \\
\text { levels of FSH } \\
\text { and E2 }\end{array}$ & 12 & $\begin{array}{c}\mathrm{CT}+\text { leuprolide } \\
\text { acetate } \\
\mathrm{CT} \text { alone }\end{array}$ & $\begin{array}{l}89 \\
94\end{array}$ & $\begin{array}{l}40.3 \\
42.1\end{array}$ & Protection \\
\hline Jiang et al. [56] & 2013 & Amenorrhea & - & $\begin{array}{c}\mathrm{CT}+\text { triptorelin } \\
\mathrm{CT} \text { alone }\end{array}$ & $\begin{array}{l}10 \\
11\end{array}$ & - & Protection \\
\hline $\begin{array}{c}\text { Karimi-Zarchi } \\
\text { et al. [57] }\end{array}$ & 2014 & Amenorrhea & 6 & $\begin{array}{c}\mathrm{CT}+\text { triptorelin } \\
\mathrm{CT} \text { alone }\end{array}$ & $\begin{array}{l}21 \\
21\end{array}$ & 37 & Protection \\
\hline $\begin{array}{l}\text { Moore et al. [60] } \\
\text { Moore et al. [63] }\end{array}$ & $\begin{array}{l}2015 \\
2019\end{array}$ & $\begin{array}{l}\text { Amenorrhea } \\
\text { and post- } \\
\text { menopausal } \\
\text { levels of FSH }\end{array}$ & 24 & $\begin{array}{c}\mathrm{CT}+\text { goserelin } \\
\mathrm{CT} \text { alone }\end{array}$ & $\begin{array}{l}105 \\
113\end{array}$ & $\begin{array}{l}37.6 \\
38.7\end{array}$ & Protection \\
\hline $\begin{array}{l}\text { Leonard } \\
\text { et al. [61] }\end{array}$ & 2017 & $\begin{array}{l}\text { Amenorrhea } \\
\text { and post- } \\
\text { menopausal } \\
\text { levels of FSH } \\
\text { and E2 }\end{array}$ & $\begin{array}{l}\text { Between } 12 \\
\text { and } 24\end{array}$ & $\begin{array}{c}\mathrm{CT}+\text { goserelin } \\
\mathrm{CT} \text { alone }\end{array}$ & $\begin{array}{l}103 \\
118\end{array}$ & $\begin{array}{l}37.9 \\
38.8\end{array}$ & Protection \\
\hline Zhang et al. [62] & 2018 & $\begin{array}{l}\text { Amenorrhea } \\
\text { and post- } \\
\text { menopausal } \\
\text { levels of FSH } \\
\text { and E2 }\end{array}$ & $36-72$ & $\begin{array}{c}\mathrm{CT}+\text { goserelin } \\
\mathrm{CT} \text { alone }\end{array}$ & $\begin{array}{l}108 \\
108\end{array}$ & $\begin{array}{c}37.5 \\
39\end{array}$ & $\begin{array}{l}\text { No } \\
\text { protection }\end{array}$ \\
\hline Zhong et al. [64] & 2019 & Amenorrhea & 12 & $\begin{array}{c}\mathrm{CT}+\text { goserelin } \\
\mathrm{CT} \text { alone }\end{array}$ & $\begin{array}{l}51 \\
45\end{array}$ & $\begin{array}{l}37.0 \\
40.0\end{array}$ & Protection \\
\hline
\end{tabular}

Abbreviations: POI, premature ovarian insufficiency; GnRHa, gonadotropin-releasing hormone agonist; $\mathrm{CT}$, chemotherapy; $\mathrm{FSH}$, folliclestimulating hormone; E2, estradiol; DFS, disease-free survival; OS, overall survival; OR, odds ratio; CI, confidence intervals; $\mathrm{HR}$, hazard ratio; RR, risk ratio. Except in four trials, all other studies demonstrated a reduction on risk of chemotherapy-induced POI with temporary ovarian suppression with GnRHa during chemotherapy. The largest trials (PROMISE-GIM6 [53,58], POEMS/SWOG S0230 [60,63] and Anglo Celtic Group OPTION [61]) showed consistent results: the addition of GnRHa during chemotherapy provided a $15 \%$ absolute reduction in POI rates. 
In this regard, most studies have reported results at such a short follow-up that an appropriate assessment of fertility preservation potential was not possible, especially in patients who are often candidates for adjuvant endocrine therapy for 5 to 10 years [66-68]. Moreover, the majority of the randomized studies also included premenopausal patients older than 40 years; most notably, the desire for conception was not an inclusion criteria. It should be highlighted that only the POEMS/SWOG S0230 study considered the number of post-treatment pregnancies as a pre-planned endpoint $[60,63]$. The study showed that the use of temporary ovarian suppression with GnRHa during chemotherapy was associated with a higher number of post-treatment pregnancies [60,63]. GnRHa administration was associated with a significantly higher number of patients conceiving after treatments also in the updated analysis of the PROMISE-GIM6 trial [58] and the Anglo Celtic Group OPTION study [61], but the absolute numbers were small and differences not significant.

Two safety concerns have been highlighted regarding temporary ovarian suppression with GnRHa during chemotherapy, particularly in patients with estrogen receptor-positive breast cancer: a potential antagonism of endocrine therapy with chemotherapy and a possible negative prognostic effect of POI prevention [69].

However, several randomized clinical trials did not demonstrate any difference in the prognosis of patients who received ovarian suppression during chemotherapy [70-72]. The TEXT and SOFT trials have also confirmed this evidence, showing no difference in the survival outcomes of premenopausal women with estrogen receptor-positive breast cancer treated with GnRHa before or following chemotherapy [73].

Furthermore, two randomized trials that evaluated the administration of GnRHa during chemotherapy also in patients with estrogen receptor-positive breast cancer and its impact on survival showed no difference in the survival outcomes; in both studies, most of the patients were also treated with GnRHa as part of their adjuvant endocrine therapy [58,62]. Recently, the results of the final analysis of the PROMISE-GIM6 trial at a median follow-up of 12.4 years have become available. This updated analysis confirmed no difference in 10-year DFS nor in 10-year OS between patients treated with chemotherapy alone, or with concurrent GnRHa, including among the cohort of women with hormone receptor-positive disease [65]. These results are reassuring concerning the safety of GnRHa use during chemotherapy as a strategy for preserving ovarian function in premenopausal patients irrespective of the hormone receptor status of their tumor.

Nevertheless, some considerations are needed to better interpret the results of these trials; most of the studies had a small sample size including less than 100 patients, median age of the included patients was close to 40 years in most of them, and the most used chemotherapy regimen was an anthracycline- and cyclophosphamide-based regimen. However, it should be remarked that the definition of chemotherapy-induced POI was based only on menstrual function after treatment in the majority of the studies. Only few studies used a composite endpoint that included both amenorrhea and post-menopausal hormonal levels and the timing for POI evaluation was also different, ranging from 6 months up to more than 5 years after the end of chemotherapy treatment. To date, there is no uniform and accepted definition of chemotherapy-induced POI. This is reflected by the use of different definitions that in most cases included amenorrhea, and in the timing of its assessment. However, amenorrhea is not an optimal surrogate marker to define the gonadotoxicity of anticancer treatments, especially in breast cancer patients who often receive adjuvant endocrine therapies (including tamoxifen), which can further impact menstrual function recovery. Experts recommend empirically to define chemotherapy-induced POI with a composite definition of amenorrhea for $\geq 2$ years and a post-menopausal hormonal profile [6,74]. Notably, only few studies reported an assessment of menstrual function at long-term and no trials assessed the final age at menopause. In the studies that evaluated AMH $[51,59,61,64,75-78]$, no difference in post-treatment AMH levels was observed between patients who received GnRHa during chemotherapy and those treated with systemic cytotoxic therapy alone. However, in all these studies, AMH was assessed in only a small proportion of randomized patients, limiting the interpretation of these results. 
Results from the available randomized trials have been summarized in several metaanalyses in order to better define the efficacy and safety of temporary ovarian suppression with GnRHa during chemotherapy in breast cancer patients (Table 2) [79-87]. Except for 2 meta-analyses, all the others demonstrated a protective effect of GnRHa administration in reducing the risk of chemotherapy-induced POI with a clearer benefit when only trials conducted in breast cancer were included. The largest and most recent meta-analyses, including the only based on individual patient level data [87], showed also a significantly higher rate of post-treatment pregnancy rate [83,84,86-88].

Table 2. Available meta-analyses evaluating temporary ovarian suppression with GnRHa during chemotherapy specifically and only in breast cancer patients.

\begin{tabular}{|c|c|c|c|c|c|}
\hline Authors & Year & Disease & $\begin{array}{l}\text { No. of Included } \\
\text { Studies } \\
\text { (No. of RCTs) }\end{array}$ & No. of Patients & Overall Results \\
\hline Yang et al. [79] & 2013 & Breast cancer & $5(5)$ & 528 & $\begin{array}{l}\text { Protection for POI (not } \\
\text { for pregnancy) }\end{array}$ \\
\hline Wang et al. [80] & 2013 & Breast cancer & $7(7)$ & 677 & Protection for POI \\
\hline Vitek et al. [81] & 2014 & $\begin{array}{c}\text { Breast cancer } \\
\text { hormone } \\
\text { receptor-negative only }\end{array}$ & $4(4)$ & 252 & No protection \\
\hline Shen et al. [82] & 2015 & Breast cancer & $11(11)$ & 1062 & $\begin{array}{l}\text { Protection for POI (not } \\
\text { for pregnancy) }\end{array}$ \\
\hline Lambertini et al. [83] & 2015 & Breast cancer & $12(12)$ & 1231 & $\begin{array}{l}\text { Protection for POI } \\
\text { (also for pregnancy) }\end{array}$ \\
\hline Munhoz et al. [84] & 2016 & Breast cancer & $7(7)$ & 856 & $\begin{array}{l}\text { Protection for POI } \\
\text { (also for pregnancy) }\end{array}$ \\
\hline Silva et al. [85] & 2016 & Breast cancer & $7(7)^{a}$ & $1002^{a}$ & Protection for POI \\
\hline Bai et al. [86] & 2017 & Breast cancer & $15(15)^{a}$ & $1540^{\mathrm{a}}$ & $\begin{array}{l}\text { Protection for POI } \\
\text { (also for pregnancy) }\end{array}$ \\
\hline Lambertini et al. [87] & 2018 & Breast cancer & $5(5)^{b}$ & 873 & $\begin{array}{l}\text { Protection for POI } \\
\text { (also for pregnancy) }\end{array}$ \\
\hline
\end{tabular}

Abbreviations: GnRHa: gonadotropin-releasing hormone agonist; POI: premature ovarian insufficiency; RCT: randomized controlled trial. ${ }^{a}$ Data from the original publication (Del Mastro et al. JAMA 2011) and the updated analysis (Lambertini M et al. JAMA 2015) of the PROMISE-GIM6 trial were considered twice instead of as from the same study. ${ }^{b}$ Based on individual patient-level data.

\subsection{Clinical Data in Patients with Malignancies Other Than Breast Cancer}

The use of GnRHa during chemotherapy as a strategy to preserve ovarian function has been considerably less investigated in women with malignancies other than breast cancer (Table 3) [75-78,89,90].

Four randomized trials have been conducted in premenopausal women with lymphoma $[75,76,78,89]$. In three of these trials, only premenopausal women with Hodgkin's lymphoma were included, while both patients with Hodgkin's and non-Hodgkin's lymphoma were included in the trial by Demeestere and colleagues. In two of these trials, chemotherapy-induced POI was defined only based on menstrual resumption after treatment, while in the other two trials it was defined on post-menopausal hormone levels after chemotherapy. In none of these trials a composite endpoint of menstrual bleeding and hormone levels was used. The timing of POI assessment was highly variable, ranging from 6 months to more than 5 years after the end of chemotherapy. In addition, it should be specified that all trials included a small number of patients, exceeding 30 patients only in the trial by Demeestere and colleagues. The chemotherapy regimens were highly different in terms of the risk of gonadotoxicity, including low-risk regimens (e.g., ABVD including doxorubicin, bleomycin, vinblastine, and dacarbazine) and high-risk regimens (such as induction regimens in hematopoietic stem cell transplants). With the limits of heterogeneous 
endpoints and timing of evaluation of the ovarian function, and with limited number of patients, all these four trials did not demonstrate a protective effect of temporary ovarian suppression with GnRHa during chemotherapy.

Table 3. Randomized trials evaluating temporary ovarian suppression with GnRHa during chemotherapy in patients with malignancies other than breast cancer.

\begin{tabular}{|c|c|c|c|c|c|c|c|c|}
\hline Authors & Year & Disease & $\begin{array}{l}\text { POI Definition } \\
\text { (Timing of Its } \\
\text { Evaluation) }\end{array}$ & $\begin{array}{l}\text { Timing POI } \\
\text { Evaluation } \\
\text { (Months) }\end{array}$ & Treatment Regimen & $\begin{array}{c}\text { No. } \\
\text { Patients }\end{array}$ & $\begin{array}{c}\text { Median } \\
\text { Age (Years) }\end{array}$ & $\begin{array}{l}\text { Overall } \\
\text { Results }\end{array}$ \\
\hline Waxman et al. [89] & 1987 & HL & Amenorrhea & Up to 36 & $\begin{array}{l}\mathrm{CT}+\text { buserelin } \\
\mathrm{CT} \text { alone }\end{array}$ & $\begin{array}{c}8 \\
10\end{array}$ & $\begin{array}{l}28.5 \\
25.9\end{array}$ & $\begin{array}{c}\text { No } \\
\text { protection }\end{array}$ \\
\hline Giuseppe et al. * [75] & 2007 & HL & Amenorrhea & NR & $\begin{array}{l}\mathrm{CT}+\text { triptorelin } \\
\mathrm{CT} \text { alone }\end{array}$ & $\begin{array}{l}14 \\
15\end{array}$ & $\begin{array}{l}24.3 \\
24.3\end{array}$ & $\begin{array}{c}\text { No } \\
\text { protection }\end{array}$ \\
\hline Gilani et al. [90] & 2007 & $\begin{array}{c}\text { Ovarian } \\
\text { Cancer }\end{array}$ & $\begin{array}{l}\text { Amenorrhea and } \\
\text { postmenopausal } \\
\text { levels of FSH }\end{array}$ & 6 & $\begin{array}{l}\mathrm{CT}+\text { triptoreline } \\
\text { CT alone }\end{array}$ & $\begin{array}{l}15 \\
15\end{array}$ & $\begin{array}{l}21 \\
22\end{array}$ & Protection \\
\hline Behringer et al. [76] & 2010 & HL & $\begin{array}{l}\text { AMH levels } \\
\text { below normal } \\
\text { range }\end{array}$ & 12 & $\begin{array}{l}\mathrm{CT}+\text { goserelin } \\
\mathrm{CT}+\mathrm{OC}\end{array}$ & $\begin{array}{l}11 \\
12\end{array}$ & $\begin{array}{l}25.3 \\
26.0\end{array}$ & $\begin{array}{c}\text { No } \\
\text { protection }\end{array}$ \\
\hline $\begin{array}{l}\text { Demeestere et al. [77] } \\
\text { Demeestere et al. [78] }\end{array}$ & $\begin{array}{l}2013 \\
2016\end{array}$ & $\begin{array}{l}\text { HL and } \\
\text { NHL }\end{array}$ & Amenorrhea & 12 & $\begin{array}{c}\mathrm{CT}+\text { triptorelin }+\mathrm{OC} \\
\mathrm{CT}+\mathrm{OC}\end{array}$ & $\begin{array}{l}45 \\
39\end{array}$ & $\begin{array}{l}25.6 \\
27.3\end{array}$ & $\begin{array}{c}\mathrm{No} \\
\text { protection }\end{array}$ \\
\hline
\end{tabular}

Abbreviations: POI, premature ovarian insufficiency; GnRHa, gonadotropin-releasing hormone agonist; HL, Hodgkin lymphoma; NHL, non-Hodgkin lymphoma; AMH, anti-Müllerian hormone; FSH, follicle-stimulating hormone; CT, chemotherapy; OC, oral contraceptives; OS, overall survival; OR, odds ratio; $\mathrm{CI}$, confidence intervals. ${ }^{*}$ The inconsistencies in methods and results pose strong doubts about the randomized nature of the study.

Only one study on the efficacy of temporary ovarian suppression with GnRHa during chemotherapy was conducted in premenopausal women with ovarian cancer. A total of 30 premenopausal women were randomized to receive chemotherapy with or without GnRHa. All women who received GnRHa during chemotherapy had a resumption of menstrual bleeding at 6 months after the end of their cytotoxic treatments, whereas $33 \%$ of women who did not receive GnRHa had chemotherapy-induced POI $(p=0.02)[73,90]$.

There are potential clinical and methodological reasons for the different results observed in patients with hematological malignancies as compared to those in the breast cancer setting.

From a clinical point of view, there are important differences between premenopausal patients with hematological diseases, particularly lymphomas, and those with breast cancer. In general, patients with hematological malignancies are characterized by a younger age at diagnosis and are treated with different chemotherapy regimens ranging from a low- to very high-risk of gonadotoxicity. Younger patients generally have a higher ovarian reserve and acute POI is usually observed only after treatment with high-risk chemotherapy regimens, whereas low- or medium-risk chemotherapy are less likely associated with POI in these patients.. On the contrary, premenopausal breast cancer patients have an average older age at diagnosis and often receive chemotherapy regimens characterized by an intermediate risk of gonadotoxicity. Therefore, the protective effect of GnRHa may become visible only in this situation and not in the case of very low or high gonadotoxicity risk.

It should be also mentioned that lymphoma patients may have a reduced ovarian reserve due to their disease even before starting anticancer therapies [91,92], whereas this has not been described so far in breast cancer patients. This issue may have implications on the differences in the obtained results.

From a methodological point of view, only four small studies with a total of 154 patients affected by lymphoma have been conducted, while to date 15 studies involving 1743 patients are available in the breast cancer setting, four of which randomized more than 200 women. The lack of power in trials concerning malignancies other than breast cancer must be considered as an important reason for the controversial results.

Several meta-analyses were performed to gather stronger data in favor of this technique in different types of cancers, and not only breast cancer (Table 4) [32,59,93-104]. 
Table 4. Available meta-analyses assessing temporary ovarian suppression with GnRHa during chemotherapy in patients with malignancies other than breast cancer or not restricted to only breast cancer trials.

\begin{tabular}{|c|c|c|c|c|c|}
\hline Authors & Year & Disease & $\begin{array}{l}\text { No. of Included } \\
\text { Studies } \\
\text { (No. of RCTs) }\end{array}$ & $\begin{array}{l}\text { No. of } \\
\text { Patients }\end{array}$ & Overall Results \\
\hline Clowse et. al. [93] & 2009 & $\begin{array}{c}\text { Autoimmune diseases, HL } \\
\text { and NHL }\end{array}$ & $9(2)$ & 366 & Protection for POI \\
\hline Ben-Aharon et al. [94] & 2010 & $\begin{array}{l}\text { Autoimmune diseases, } \\
\text { breast cancer, HL and NHL }\end{array}$ & $16(5)$ & 681 & $\begin{array}{l}\text { Protection for POI } \\
\quad \text { (not in RCTs) }\end{array}$ \\
\hline Kim et al. [95] & 2010 & $\begin{array}{c}\text { Autoimmune diseases, } \\
\text { breast cancer, HL and NHL }\end{array}$ & $11(3)$ & 654 & Protection for POI \\
\hline Bedaiwy et al. [96] & 2011 & $\begin{array}{l}\text { Breast cancer, ovarian } \\
\text { cancer and HL }\end{array}$ & $6(6)$ & 340 & $\begin{array}{l}\text { Protection for POI } \\
\text { (not for pregnancy) }\end{array}$ \\
\hline Zhang et al. [97] & 2013 & HL and NHL & $7(3)$ & 434 & $\begin{array}{l}\text { Protection for POI } \\
\text { (not for pregnancy) }\end{array}$ \\
\hline Sun et al. [98] & 2014 & $\begin{array}{l}\text { Breast cancer, ovarian } \\
\text { cancer and HL }\end{array}$ & $8(8)$ & 621 & $\begin{array}{l}\text { Protection for POI } \\
\text { (not for pregnancy) }\end{array}$ \\
\hline Del Mastro et al. [99] & 2014 & $\begin{array}{l}\text { Breast cancer, ovarian } \\
\text { cancer, HL and NHL }\end{array}$ & $9(9)$ & 765 & Protection for POI \\
\hline Elgindy et al. [59] & 2015 & $\begin{array}{l}\text { Breast cancer, ovarian } \\
\text { cancer, HL and NHL }\end{array}$ & $10(10)$ & 907 & No protection \\
\hline Senra et al. [100] & 2018 & Breast cancer, HL and NHL & $13(13)$ & 1208 & $\begin{array}{c}\text { Protection for POI } \\
\text { (also for } \\
\text { pregnancy) }\end{array}$ \\
\hline Hickman et al. [101] & 2018 & $\begin{array}{l}\text { Breast cancer, ovarian } \\
\text { cancer, HL and NHL }\end{array}$ & $10(10)$ & 1051 & Protection for POI \\
\hline Sofiyeva et al. [102] & 2019 & $\begin{array}{l}\text { Autoimmune diseases, } \\
\text { breast cancer, HL and NHL }\end{array}$ & $18(11)$ & 1043 & Protection for POI \\
\hline Zheng et al. [103] & 2019 & Breast cancer, $\mathrm{HL}$ and NHL & $12(12)$ & 1413 & $\begin{array}{l}\text { Protection for POI } \\
\text { (not for pregnancy) }\end{array}$ \\
\hline Chen et al. [104] & 2019 & $\begin{array}{l}\text { Breast cancer, ovarian } \\
\text { cancer and HL }\end{array}$ & $12(12)$ & 1369 & $\begin{array}{l}\text { Protection for POI } \\
\text { (not for pregnancy) }\end{array}$ \\
\hline Luong et al. [105] & 2020 & Autoimmune diseases & $3(1)$ & 93 & Protection for POI \\
\hline
\end{tabular}

Abbreviations: POI, premature ovarian insufficiency; GnRHa, gonadotropin-releasing hormone agonist; HL, Hodgkin lymphoma; NHL, non-Hodgkin lymphoma.

Among these meta-analyses, all but one showed that the use of GnRHa during chemotherapy has a protective effect on the risk of POI, while only one of them showed that this technique could increase the probability of spontaneous pregnancy in the shortterm after the end of treatments [100]. However, only 3 of these meta-analyses $[93,97,105]$ included exclusively patients with malignancies other than breast cancer (HL and NHL and autoimmune diseases in particular).

Several limitations are present in these meta-analyses due to differences in the included trials. First, as mentioned above, different definitions of POI were used in the study and the limited duration of the follow-up of the trials precluded the ability to determine the longterm impact of GnRHa on the preservation of ovarian function and fertility. In addition, a moderate heterogeneity among the studies is also due to the different chemotherapy regimens administered that have been modified in clinical practice over the years and may have partially affected the outcomes of the trials included in the meta-analyses.

\section{Conclusions}

Despite continuous research efforts in this field, many physicians and patients are still concerned about discussing preservation of ovarian function and fertility for the fear that 
the proposed strategies may have a negative effect on oncological outcomes [8]. Thanks to constant reassuring data about the safety of conceiving following the completion of anticancer treatments [106], it is increasingly important to conduct a proper oncofertility counselling in all patients in order to increase their possibility of completing their family building plan. Even more importantly, it is essential to ensure that all women can experience a quality of life as equal as possible to that of healthy women from the general population. Hence, protecting ovarian function and avoiding all the side effects associated with POI is of primary importance $[1,6]$.

POI development is potentially a direct effect of gonadotoxic therapies in all premenopausal cancer patients; the use of adjuvant endocrine treatments for many years after diagnosis can further amplify this issue [107]. To date, with the exception of deescalation of chemotherapy in selected patients, the only recognized and approved method to protect ovarian function in premenopausal women undergoing cytotoxic therapy is the concomitant use of GnRHa [1].

However, it must be highlighted that most of the available randomized trials assessing the use of GnRHa during chemotherapy have been conducted in breast cancer patients, with limited and mostly negative evidence in women with hematological malignancies. Nevertheless, also in the setting of hematological malignancies, GnRHa during chemotherapy could be taken into consideration to prevent menometrorrhagia by controlling the menstrual cycle [1]. The main concepts presented in this work are summarized in Table 5.

Table 5. Overview of the main concepts concerning the use of GnRHa in reducing the risk of POI in patients undergoing gonadotoxic treatments.

\begin{tabular}{cc}
\hline \multicolumn{1}{c}{ Questions } & Summary \\
\hline $\begin{array}{c}\text { How can we estimate the risk of } \\
\text { treatment-induced gonadotoxicity? }\end{array}$ & $\begin{array}{c}\text { The risk of treatment-induced gonadotoxicity is influenced by patient-related (i.e., age and } \\
\text { genetic) and treatment-related (i.e., type and dose of chemotherapy) factors. Limited data } \\
\text { exist to date on the possible gonadotoxic effect of new drug such as monoclonal antibodies } \\
\text { or PARP inhibitors. }\end{array}$ \\
\hline $\begin{array}{c}\text { Is de-escalation of cancer treatment } \\
\text { a valid and safe option to reduce } \\
\text { treatment-related gonadotoxicity? }\end{array}$ & $\begin{array}{c}\text { Due to the development of increasingly individualized anticancer therapies, particularly for } \\
\text { early-stage cancer, a growing attention has been paid in tailoring type and intensity of } \\
\text { systemic therapies, balancing between the individual risk of cancer relapse and toxicity. In } \\
\text { some setting, de-escalation of chemotherapy is possible with lower rate of } \\
\text { treatment-induced amenorrhea in front of similar survival outcomes. }\end{array}$ \\
$\begin{array}{c}\text { Is ovarian suppression with GnRHa } \\
\text { during chemotherapy a valid and } \\
\text { safe option to reduce }\end{array}$ & $\begin{array}{c}\text { Use of GnRHa during treatment aiming to prevent chemotherapy-induced POI has been } \\
\text { evaluated in different diseases with a special focus in breast cancer patients. In this setting, } \\
\text { most of the trials demonstrated a reduction in the risk of chemotherapy-induced POI, } \\
\text { irrespective of hormone receptor status. This technique has been considerably less } \\
\text { investigated in women with malignancies other than breast cancer, with mostly negative } \\
\text { results. Overall, based on its efficay and safety data, this technique should be offered to } \\
\text { patients that receive chemotherapy and want to preserve ovarian function, particulalry to } \\
\text { those with breast cancer. }\end{array}$ \\
\hline
\end{tabular}

Abbreviations: GnRHa, gonadotropin-releasing hormone agonist; POI, premature ovarian insufficiency.

Importantly, it should be remembered that, for patients interested in fertility preservation, temporary ovarian suppression with a GnRHa during chemotherapy is not an alternative to cryopreservation techniques $[1,6]$.

The main limitation of the current evidence, in addition to the limited data outside the breast cancer field, is the short follow-up of most of the randomized trials without the possibility of evaluating the long-term outcomes, including post-treatment pregnancies and age at menopause. Moreover, collecting information on ovarian reserve markers during treatment and follow-up should be planned in all new trials that want to investigate the effect of cancer treatments on ovarian reserve and the impact on POI.

Besides GnRHa during chemotherapy, other pharmacological and biomedical techniques that can prevent POI in these patients are under constant development [9], but they are still in early phase of development. 
Author Contributions: All the authors contributed equally to the development of this manuscript. All authors have read and agreed to the published version of the manuscript.

Funding: M.L. is supported by the Associazione Italiana per la Ricerca sul Cancro (AIRC; grant number MFAG 2020 ID 24698) and the Italian Ministry of Health $-5 \times 1000$ funds 2017 (no grant number) for pursuing in his research efforts in the field of oncofertility.

Data Availability Statement: Data sharing not applicable. No new data were created or analyzed in this study. Data sharing is not applicable to this article.

Conflicts of Interest: M.L. acted as consultant for Roche, AstraZeneca, Eli Lilly, Exact Sciences and Novartis, and received speaker honoraria from Roche, Sandoz, Takeda, Pfizer, Eli Lilly, and Novartis outside the submitted work. The other authors declare no conflict of interest.

\section{References}

1. Lambertini, M.; Peccatori, F.A.; Demeestere, I.; Amant, F.; Wyns, C.; Stukenborg, J.-B.; Paluch-Shimon, S.; Halaska, M.J.; Uzan, C.; Meissner, J.; et al. Fertility Preservation and Post-Treatment Pregnancies in Post-Pubertal Cancer Patients: ESMO Clinical Practice Guidelines. Ann. Oncol. 2020, 31, 1664-1678. [CrossRef]

2. Perachino, M.; Massarotti, C.; Razeti, M.G.; Parisi, F.; Arecco, L.; Damassi, A.; Fregatti, P.; Solinas, C.; Lambertini, M. GenderSpecific Aspects Related to Type of Fertility Preservation Strategies and Access to Fertility Care. ESMO Open 2020, 5 , e000771. [CrossRef]

3. Howard-Anderson, J.; Ganz, P.A.; Bower, J.E.; Stanton, A.L. Quality of Life, Fertility Concerns, and Behavioral Health Outcomes in Younger Breast Cancer Survivors: A Systematic Review. JNCI J. Natl. Cancer Inst. 2012, 104, 386-405. [CrossRef] [PubMed]

4. Van Dorp, W.; Haupt, R.; Anderson, R.A.; Mulder, R.L.; van den Heuvel-Eibrink, M.M.; van Dulmen-den Broeder, E.; Su, H.I.; Winther, J.F.; Hudson, M.M.; Levine, J.M.; et al. Reproductive Function and Outcomes in Female Survivors of Childhood, Adolescent, and Young Adult Cancer: A Review. J. Clin. Oncol. 2018, 36, 2169-2180. [CrossRef] [PubMed]

5. Fidler, M.M.; Gupta, S.; Soerjomataram, I.; Ferlay, J.; Steliarova-Foucher, E.; Bray, F. Cancer Incidence and Mortality among Young Adults Aged 20-39 Years Worldwide in 2012: A Population-Based Study. Lancet Oncol. 2017, 18, 1579-1589. [CrossRef]

6. The ESHRE Guideline Group on Female Fertility Preservation; Anderson, R.A.; Amant, F.; Braat, D.; D’Angelo, A.; Chuva de Sousa Lopes, S.M.; Demeestere, I.; Dwek, S.; Frith, L.; Lambertini, M.; et al. ESHRE Guideline: Female Fertility Preservation. Hum. Reprod. Open 2020, 2020, hoaa052. [CrossRef]

7. Lambertini, M.; Horicks, F.; Del Mastro, L.; Partridge, A.H.; Demeestere, I. Ovarian Protection with Gonadotropin-Releasing Hormone Agonists during Chemotherapy in Cancer Patients: From Biological Evidence to Clinical Application. Cancer Treat. Rev. 2019, 72, 65-77. [CrossRef] [PubMed]

8. Blondeaux, E.; Massarotti, C.; Fontana, V.; Poggio, F.; Arecco, L.; Fregatti, P.; Bighin, C.; Giannubilo, I.; Ruelle, T.; Razeti, M.G.; et al. The PREgnancy and FERtility (PREFER) Study Investigating the Need for Ovarian Function and/or Fertility Preservation Strategies in Premenopausal Women with Early Breast Cancer. Front. Oncol. 2021, 11, 690320. [CrossRef]

9. Spears, N.; Lopes, F.; Stefansdottir, A.; Rossi, V.; De Felici, M.; Anderson, R.A.; Klinger, F.G. Ovarian Damage from Chemotherapy and Current Approaches to Its Protection. Hum. Reprod. Update 2019, 25, 673-693. [CrossRef] [PubMed]

10. Turan, V.; Lambertini, M.; Lee, D.-Y.; Wang, E.; Clatot, F.; Karlan, B.Y.; Demeestere, I.; Bang, H.; Oktay, K. Association of Germline BRCA Pathogenic Variants with Diminished Ovarian Reserve: A Meta-Analysis of Individual Patient-Level Data. J. Clin. Oncol. 2021, 39, 2016-2024. [CrossRef]

11. Valentini, A.; Finch, A.; Lubinski, J.; Byrski, T.; Ghadirian, P.; Kim-Sing, C.; Lynch, H.T.; Ainsworth, P.J.; Neuhausen, S.L.; Greenblatt, E.; et al. Chemotherapy-Induced Amenorrhea in Patients with Breast Cancer with a BRCA1 or BRCA2 Mutation. J. Clin. Oncol. 2013, 31, 3914-3919. [CrossRef] [PubMed]

12. Lambertini, M.; Olympios, N.; Lequesne, J.; Calbrix, C.; Fontanilles, M.; Loeb, A.; Leheurteur, M.; Demeestere, I.; Di Fiore, F.; Perdrix, A.; et al. Impact of Taxanes, Endocrine Therapy, and Deleterious Germline BRCA Mutations on Anti-Müllerian Hormone Levels in Early Breast Cancer Patients Treated with Anthracycline- and Cyclophosphamide-Based Chemotherapy. Front. Oncol. 2019, 9, 575. [CrossRef]

13. Oktay, K.H.; Bedoschi, G.; Goldfarb, S.B.; Taylan, E.; Titus, S.; Palomaki, G.E.; Cigler, T.; Robson, M.; Dickler, M.N. Increased Chemotherapy-Induced Ovarian Reserve Loss in Women with Germline BRCA Mutations Due to Oocyte Deoxyribonucleic Acid Double Strand Break Repair Deficiency. Fertil. Steril. 2020, 113, 1251-1260.e1. [CrossRef] [PubMed]

14. Goldman, K.N.; Chenette, D.; Arju, R.; Duncan, F.E.; Keefe, D.L.; Grifo, J.A.; Schneider, R.J. MTORC1/2 Inhibition Preserves Ovarian Function and Fertility during Genotoxic Chemotherapy. Proc. Natl. Acad. Sci. USA 2017, 114, 3186-3191. [CrossRef] [PubMed]

15. Codacci-Pisanelli, G.; Del Pup, L.; Del Grande, M.; Peccatori, F.A. Mechanisms of Chemotherapy-Induced Ovarian Damage in Breast Cancer Patients. Crit. Rev. Oncol. Hematol. 2017, 113, 90-96. [CrossRef]

16. Lambertini, M.; Del Mastro, L.; Pescio, M.C.; Andersen, C.Y.; Azim, H.A.; Peccatori, F.A.; Costa, M.; Revelli, A.; Salvagno, F.; Gennari, A.; et al. Cancer and Fertility Preservation: International Recommendations from an Expert Meeting. BMC Med. 2016, 14, 1. [CrossRef] 
17. Zhao, J.; Liu, J.; Chen, K.; Li, S.; Wang, Y.; Yang, Y.; Deng, H.; Jia, W.; Rao, N.; Liu, Q.; et al. What Lies behind ChemotherapyInduced Amenorrhea for Breast Cancer Patients: A Meta-Analysis. Breast Cancer Res. Treat. 2014, 145, 113-128. [CrossRef]

18. Lambertini, M.; Campbell, C.; Bines, J.; Korde, L.A.; Izquierdo, M.; Fumagalli, D.; Del Mastro, L.; Ignatiadis, M.; Pritchard, K.; Wolff, A.C.; et al. Adjuvant Anti-HER2 Therapy, Treatment-Related Amenorrhea, and Survival in Premenopausal HER2-Positive Early Breast Cancer Patients. JNCI J. Natl. Cancer Inst. 2019, 111, 86-94. [CrossRef]

19. Winship, A.L.; Griffiths, M.; Lliberos Requesens, C.; Sarma, U.; Phillips, K.-A.; Hutt, K.J. The PARP Inhibitor, Olaparib, Depletes the Ovarian Reserve in Mice: Implications for Fertility Preservation. Hum. Reprod. 2020, 35, 1864-1874. [CrossRef]

20. Van Ramshorst, M.S.; van der Voort, A.; van Werkhoven, E.D.; Mandjes, I.A.; Kemper, I.; Dezentjé, V.O.; Oving, I.M.; Honkoop, A.H.; Tick, L.W.; van de Wouw, A.J.; et al. Neoadjuvant Chemotherapy with or without Anthracyclines in the Presence of Dual HER2 Blockade for HER2-Positive Breast Cancer (TRAIN-2): A Multicentre, Open-Label, Randomised, Phase 3 Trial. Lancet Oncol. 2018, 19, 1630-1640. [CrossRef]

21. Tolaney, S.M.; Guo, H.; Pernas, S.; Barry, W.T.; Dillon, D.A.; Ritterhouse, L.; Schneider, B.P.; Shen, F.; Fuhrman, K.; Baltay, M.; et al. Seven-Year Follow-Up Analysis of Adjuvant Paclitaxel and Trastuzumab Trial for Node-Negative, Human Epidermal Growth Factor Receptor 2-Positive Breast Cancer. J. Clin. Oncol. 2019, 37, 1868-1875. [CrossRef] [PubMed]

22. Tolaney, S.M.; Tayob, N.; Dang, C.; Yardley, D.A.; Isakoff, S.J.; Valero, V.; Faggen, M.; Mulvey, T.; Bose, R.; Hu, J.; et al. Adjuvant Trastuzumab Emtansine Versus Paclitaxel in Combination with Trastuzumab for Stage I HER2-Positive Breast Cancer (ATEMPT): A Randomized Clinical Trial. J. Clin. Oncol. 2021, 39, 2375-2385. [CrossRef]

23. Yu, K.-D.; Ge, J.-Y.; Liu, X.-Y.; Mo, M.; He, M.; Shao, Z.-M.; SPECTRUM Investigators. Cyclophosphamide-Free Adjuvant Chemotherapy for Ovarian Protection in Young Women with Breast Cancer: A Randomized Phase 3 Trial. JNCI J. Natl. Cancer Inst. 2021, djab065. [CrossRef]

24. Ruddy, K.J.; Guo, H.; Barry, W.; Dang, C.T.; Yardley, D.A.; Moy, B.; Marcom, P.K.; Albain, K.S.; Rugo, H.S.; Ellis, M.J.; et al. Chemotherapy-Related Amenorrhea after Adjuvant Paclitaxel-Trastuzumab (APT Trial). Breast Cancer Res. Treat. 2015, 151, 589-596. [CrossRef]

25. Molinelli, C.; Parisi, F.; Razeti, M.G.; Arecco, L.; Cosso, M.; Fregatti, P.; Del Mastro, L.; Poggio, F.; Lambertini, M. Trastuzumab Emtansine (T-DM1) as Adjuvant Treatment of HER2-Positive Early Breast Cancer: Safety and Efficacy. Expert Rev. Anticancer Ther. 2021, 21, 241-250. [CrossRef] [PubMed]

26. Ruddy, K.J.; Zheng, Y.; Tayob, N.; Hu, J.; Dang, C.T.; Yardley, D.A.; Isakoff, S.J.; Valero, V.V.; Faggen, M.G.; Mulvey, T.M.; et al. Chemotherapy-Related Amenorrhea (CRA) after Adjuvant Ado-Trastuzumab Emtansine (T-DM1) Compared to Paclitaxel in Combination with Trastuzumab (TH) (TBCRC033: ATEMPT Trial). Breast Cancer Res. Treat. 2021, 189, 103-110. [CrossRef]

27. Van der Voort, A.; van Ramshorst, M.S.; van Werkhoven, E.D.; Mandjes, I.A.; Kemper, I.; Vulink, A.J.; Oving, I.M.; Honkoop, A.H.; Tick, L.W.; van de Wouw, A.J.; et al. Three-Year Follow-up of Neoadjuvant Chemotherapy with or without Anthracyclines in the Presence of Dual ERBB2 Blockade in Patients With ERBB2-Positive Breast Cancer: A Secondary Analysis of the TRAIN-2 Randomized, Phase 3 Trial. JAMA Oncol. 2021, 7, 978-984. [CrossRef]

28. Lambertini, M.; Partridge, A.H. Cyclophosphamide-Free Adjuvant Chemotherapy for the Potential Prevention of Premature Ovarian Insufficiency and Infertility in Young Women with Breast Cancer. J. Natl. Cancer Inst. 2021, djab066. [CrossRef]

29. Kitajima, Y.; Endo, T.; Nagasawa, K.; Manase, K.; Honnma, H.; Baba, T.; Hayashi, T.; Chiba, H.; Sawada, N.; Saito, T. Hyperstimulation and a Gonadotropin-Releasing Hormone Agonist Modulate Ovarian Vascular Permeability by Altering Expression of the Tight Junction Protein Claudin-5. Endocrinology 2006, 147, 694-699. [CrossRef] [PubMed]

30. Poggio, F.; Lambertini, M.; Bighin, C.; Conte, B.; Blondeaux, E.; D’Alonzo, A.; Dellepiane, C.; Buzzatti, G.; Molinelli, C.; Boccardo, F.; et al. Potential Mechanisms of Ovarian Protection with Gonadotropin-Releasing Hormone Agonist in Breast Cancer Patients: A Review. Clin. Med. Insights Reprod. Health 2019, 13. [CrossRef]

31. Dolmans, M.-M.; Taylor, H.S.; Rodriguez-Wallberg, K.A.; Blumenfeld, Z.; Lambertini, M.; von Wolff, M.; Donnez, J. Utility of Gonadotropin-Releasing Hormone Agonists for Fertility Preservation in Women Receiving Chemotherapy: Pros and Cons. Fertil. Steril. 2020, 114, 725-738. [CrossRef]

32. Ben-Aharon, I.; Shalgi, R. What Lies behind Chemotherapy-Induced Ovarian Toxicity? Reproduction 2012, 144, 153-163. [CrossRef]

33. Blumenfeld, Z. How to Preserve Fertility in Young Women Exposed to Chemotherapy? The Role of GnRH Agonist Cotreatment in Addition to Cryopreservation of Embrya, Oocytes, or Ovaries. Oncologist 2007, 12, 1044-1054. [CrossRef]

34. Chapman, R.; Sutcliffe, S. Protection of Ovarian Function by Oral Contraceptives in Women Receiving Chemotherapy for Hodgkin's Disease. Blood 1981, 58, 849-851. [CrossRef] [PubMed]

35. Hasky, N.; Uri-Belapolsky, S.; Goldberg, K.; Miller, I.; Grossman, H.; Stemmer, S.M.; Ben-Aharon, I.; Shalgi, R. GonadotrophinReleasing Hormone Agonists for Fertility Preservation: Unraveling the Enigma? Hum. Reprod. 2015, 30, 1089-1101. [CrossRef]

36. Sánchez, F.; Smitz, J. Molecular Control of Oogenesis. Biochim. Biophys. Acta Mol. Basis Dis. 2012, 1822, 1896-1912. [CrossRef] [PubMed]

37. Whitelaw, P.F.; Eidne, K.A.; Sellar, R.; Smyth, C.D.; Hillier, S.G. Gonadotropin-Releasing Hormone Receptor Messenger Ribonucleic Acid Expression in Rat Ovary. Endocrinology 1995, 136, 172-179. [CrossRef] [PubMed]

38. Harrison, G.S.; Wierman, M.E.; Nett, T.M.; Glode, L.M. Gonadotropin-Releasing Hormone and Its Receptor in Normal and Malignant Cells. Endocr. Relat. Cancer 2004, 11, 725-748. [CrossRef]

39. Soleimani, R.; Heytens, E.; Oktay, K. Enhancement of Neoangiogenesis and Follicle Survival by Sphingosine-1-Phosphate in Human Ovarian Tissue Xenotransplants. PLoS ONE 2011, 6, e19475. [CrossRef] [PubMed] 
40. Morita, Y.; Perez, G.I.; Paris, F.; Miranda, S.R.; Ehleiter, D.; Haimovitz-Friedman, A.; Fuks, Z.; Xie, Z.; Reed, J.C.; Schuchman, E.H.; et al. Oocyte Apoptosis Is Suppressed by Disruption of the Acid Sphingomyelinase Gene or by Sphingosine-1-Phosphate Therapy. Nat. Med. 2000, 6, 1109-1114. [CrossRef] [PubMed]

41. Li, F.; Turan, V.; Lierman, S.; Cuvelier, C.; De Sutter, P.; Oktay, K. Sphingosine-1-Phosphate Prevents Chemotherapy-Induced Human Primordial Follicle Death. Hum. Reprod. 2014, 29, 107-113. [CrossRef]

42. Johnson, J.; Canning, J.; Kaneko, T.; Pru, J.K.; Tilly, J.L. Germline Stem Cells and Follicular Renewal in the Postnatal Mammalian Ovary. Nature 2004, 428, 145-150. [CrossRef]

43. Sobinoff, A.P.; Nixon, B.; Roman, S.D.; McLaughlin, E.A. Staying Alive: PI3K Pathway Promotes Primordial Follicle Activation and Survival in Response to 3MC-Induced Ovotoxicity. Toxicol. Sci. 2012, 128, 258-271. [CrossRef]

44. Kalich-Philosoph, L.; Roness, H.; Carmely, A.; Fishel-Bartal, M.; Ligumsky, H.; Paglin, S.; Wolf, I.; Kanety, H.; Sredni, B.; Meirow, D. Cyclophosphamide Triggers Follicle Activation and "Burnout"; AS101 Prevents Follicle Loss and Preserves Fertility. Sci. Transl. Med. 2013, 5, 185ra62. [CrossRef] [PubMed]

45. Scaruffi, P.; Stigliani, S.; Cardinali, B.; Massarotti, C.; Lambertini, M.; Sozzi, F.; Dellepiane, C.; Merlo, D.F.; Anserini, P.; Del Mastro, L. Gonadotropin Releasing Hormone Agonists Have an Anti-Apoptotic Effect on Cumulus Cells. Int. J. Mol. Sci. 2019, $20,6045$. [CrossRef]

46. Bildik, G.; Akin, N.; Senbabaoglu, F.; Sahin, G.N.; Karahuseyinoglu, S.; Ince, U.; Taskiran, C.; Selek, U.; Yakin, K.; Guzel, Y.; et al. GnRH Agonist Leuprolide Acetate Does Not Confer Any Protection against Ovarian Damage Induced by Chemotherapy and Radiation in Vitro. Hum. Reprod. 2015, 30, 2912-2925. [CrossRef]

47. Lambertini, M.; Richard, F.; Nguyen, B.; Viglietti, G.; Villarreal-Garza, C. Ovarian Function and Fertility Preservation in Breast Cancer: Should Gonadotropin-Releasing Hormone Agonist Be Administered to All Premenopausal Patients Receiving Chemotherapy? Clin. Med. Insights Reprod. Health 2019, 13. [CrossRef] [PubMed]

48. Li, M.; Huang, H.; Liang, Y.; Tan, J.; Lin, D. Effect of Zoladex Administered before Chemotherapy on Menstruation of Patients with Breast Cancer. Chin. J. Clin. Oncol. 2008, 35, 905-907.

49. Badawy, A.; Elnashar, A.; El-Ashry, M.; Shahat, M. Gonadotropin-Releasing Hormone Agonists for Prevention of ChemotherapyInduced Ovarian Damage: Prospective Randomized Study. Fertil. Steril. 2009, 91, 694-697. [CrossRef]

50. Sverrisdottir, A.; Nystedt, M.; Johansson, H.; Fornander, T. Adjuvant Goserelin and Ovarian Preservation in Chemotherapy Treated Patients with Early Breast Cancer: Results from a Randomized Trial. Breast Cancer Res. Treat. 2009, 117, 561-567. [CrossRef] [PubMed]

51. Gerber, B.; von Minckwitz, G.; Stehle, H.; Reimer, T.; Felberbaum, R.; Maass, N.; Fischer, D.; Sommer, H.L.; Conrad, B.; Ortmann, O.; et al. Effect of Luteinizing Hormone-Releasing Hormone Agonist on Ovarian Function after Modern Adjuvant Breast Cancer Chemotherapy: The GBG 37 ZORO Study. J. Clin. Oncol. 2011, 29, 2334-2341. [CrossRef]

52. Sun, J.; Ren, Y.; Li, W. Effect of Zoladex Administered before Chemotherapy on Menstruation of Patients with Breast Cancer. Chin. Disab. Med. 2011, 19, 15-16.

53. Del Mastro, L.; Boni, L.; Michelotti, A.; Gamucci, T.; Olmeo, N.; Gori, S.; Giordano, M.; Garrone, O.; Pronzato, P.; Bighin, C.; et al. Effect of the Gonadotropin-Releasing Hormone Analogue Triptorelin on the Occurrence of Chemotherapy-Induced Early Menopause in Premenopausal Women with Breast Cancer: A Randomized Trial. JAMA 2011, 306, 269-276. [CrossRef] [PubMed]

54. Munster, P.N.; Moore, A.P.; Ismail-Khan, R.; Cox, C.E.; Lacevic, M.; Gross-King, M.; Xu, P.; Carter, W.B.; Minton, S.E. Randomized Trial Using Gonadotropin-Releasing Hormone Agonist Triptorelin for the Preservation of Ovarian Function During (Neo)Adjuvant Chemotherapy for Breast Cancer. J. Clin. Oncol. 2012, 30, 533-538. [CrossRef]

55. Song, G.; Gao, H.; Yuan, Z. Effect of Leuprolide Acetate on Ovarian Function after Cyclophosphamide-Doxorubicin-Based Chemotherapy in Premenopausal Patients with Breast Cancer: Results from a Phase II Randomized Trial. Med. Oncol. 2013, 30, 667. [CrossRef]

56. Jiang, F.Y.; Zhang, Q.Q.; Zeng, J. Protective Effect of GnRHa on Chemotherapy Induced Ovarian Damage in Breast Cancer Patients. Shandong Med. J. 2013, 53, 16-18.

57. Karimi-Zarchi, M.; Forat-Yazdi, M.; Vafaeenasab, M.R.; Nakhaie-Moghadam, M.; Miratashi-Yazdi, A.; Teimoori, S.; Dehghani-Tafti, A. Evaluation of the Effect of GnRH Agonist on Menstrual Reverse in Breast Cancer Cases Treated with Cyclophosphamide. Eur. J. Gynaecol. Oncol. 2014, 35, 59-61.

58. Lambertini, M.; Boni, L.; Michelotti, A.; Gamucci, T.; Scotto, T.; Gori, S.; Giordano, M.; Garrone, O.; Levaggi, A.; Poggio, F.; et al. Ovarian Suppression with Triptorelin During Adjuvant Breast Cancer Chemotherapy and Long-Term Ovarian Function, Pregnancies, and Disease-Free Survival: A Randomized Clinical Trial. JAMA 2015, 314, 2632-2640. [CrossRef]

59. Elgindy, E.; Sibai, H.; Abdelghani, A.; Mostafa, M. Protecting Ovaries During Chemotherapy Through Gonad Suppression: A Systematic Review and Meta-Analysis. Obstet. Gynecol. 2015, 126, 187-195. [CrossRef]

60. Moore, H.C.F.; Unger, J.M.; Phillips, K.-A.; Boyle, F.; Hitre, E.; Porter, D.; Francis, P.A.; Goldstein, L.J.; Gomez, H.L.; Vallejos, C.S.; et al. Goserelin for Ovarian Protection during Breast-Cancer Adjuvant Chemotherapy. N. Engl. J. Med. 2015, 372, 923-932. [CrossRef] [PubMed]

61. Leonard, R.C.F.; Adamson, D.J.A.; Bertelli, G.; Mansi, J.; Yellowlees, A.; Dunlop, J.; Thomas, G.A.; Coleman, R.E.; Anderson, R.A. GnRH Agonist for Protection against Ovarian Toxicity during Chemotherapy for Early Breast Cancer: The Anglo Celtic Group OPTION Trial. Ann. Oncol. 2017, 28, 1811-1816. [CrossRef] 
62. Zhang, Y.; Ji, Y.; Li, J.; Lei, L.; Wu, S.; Zuo, W.; Jia, X.; Wang, Y.; Mo, M.; Zhang, N.; et al. Sequential versus Simultaneous Use of Chemotherapy and Gonadotropin-Releasing Hormone Agonist (GnRHa) among Estrogen Receptor (ER)-Positive Premenopausal Breast Cancer Patients: Effects on Ovarian Function, Disease-Free Survival, and Overall Survival. Breast Cancer Res. Treat. 2018, 168, 679-686. [CrossRef] [PubMed]

63. Moore, H.C.F.; Unger, J.M.; Phillips, K.-A.; Boyle, F.; Hitre, E.; Moseley, A.; Porter, D.J.; Francis, P.A.; Goldstein, L.J.; Gomez, H.L.; et al. Final Analysis of the Prevention of Early Menopause Study (POEMS)/SWOG Intergroup S0230. JNCI J. Natl. Cancer Inst. 2019, 111, 210-213. [CrossRef]

64. Zhong, Y.; Lin, Y.; Cheng, X.; Huang, X.; Zhou, Y.; Mao, F.; Wang, Y.; Guan, J.; Shen, S.; Xu, Y.; et al. GnRHa for Ovarian Protection and the Association between AMH and Ovarian Function during Adjuvant Chemotherapy for Breast Cancer. J. Cancer 2019, 10, 4278-4285. [CrossRef] [PubMed]

65. Lambertini, M.; Boni, L.; Michelotti, A.; Magnolfi, E.; Cogoni, A.A.; Mosconi, A.M.; Giordano, M.; Garrone, O.; Arpino, G.; Poggio, F.; et al. Final analysis of the PROMISE-GIM6 phase III trial assessing GnRH agonist use during chemotherapy as a strategy to preserve ovarian function in premenopausal patients with early breast cancer. J. Clin. Oncol. 2021, 39, 516. [CrossRef]

66. Burstein, H.J.; Lacchetti, C.; Anderson, H.; Buchholz, T.A.; Davidson, N.E.; Gelmon, K.E.; Giordano, S.H.; Hudis, C.A.; Solky, A.J.; Stearns, V.; et al. Adjuvant Endocrine Therapy for Women with Hormone Receptor-Positive Breast Cancer: American Society of Clinical Oncology Clinical Practice Guideline Update on Ovarian Suppression. J. Clin. Oncol. 2016, 34, 1689-1701. [CrossRef] [PubMed]

67. Gori, S.; Puglisi, F.; Cinquini, M.; Pappagallo, G.; Frassoldati, A.; Biganzoli, L.; Cortesi, L.; Fiorentino, A.; Angiolini, C.; Tinterri, C.; et al. Adjuvant Endocrine Therapy in Premenopausal Patients with Hormone Receptor-Positive Early Breast Cancer: Evidence Evaluation and GRADE Recommendations by the Italian Association of Medical Oncology (AIOM). Eur. J. Cancer 2018, 99, 9-19. [CrossRef]

68. Lambertini, M.; Blondeaux, E.; Perrone, F.; Del Mastro, L. Improving Adjuvant Endocrine Treatment Tailoring in Premenopausal Women with Hormone Receptor-Positive Breast Cancer. J. Clin. Oncol. 2019, 38, 1258-1267. [CrossRef]

69. Rugo, H.S.; Rosen, M.P. Reducing the Long-Term Effects of Chemotherapy in Young Women with Early-Stage Breast Cancer. JAMA 2011, 306, 312-314. [CrossRef] [PubMed]

70. International Breast Cancer Study Group. Late Effects of Adjuvant Oophorectomy and Chemotherapy upon Premenopausal Breast Cancer Patients. Ann. Oncol. 1990, 1, 30-35. [CrossRef]

71. Rivkin, S.E.; Green, S.; O’Sullivan, J.; Cruz, A.B.; Abeloff, M.D.; Jewell, W.R.; Costanzi, J.J.; Farrar, W.B.; Osborne, C.K. Adjuvant CMFVP versus Adjuvant CMFVP plus Ovariectomy for Premenopausal, Node-Positive, and Estrogen Receptor-Positive Breast Cancer Patients: A Southwest Oncology Group Study. J. Clin. Oncol. 1996, 14, 46-51. [CrossRef] [PubMed]

72. Arriagada, R.; Lê, M.G.; Spielmann, M.; Mauriac, L.; Bonneterre, J.; Namer, M.; Delozier, T.; Hill, C.; Tursz, T. Randomized Trial of Adjuvant Ovarian Suppression in 926 Premenopausal Patients with Early Breast Cancer Treated with Adjuvant Chemotherapy. Ann. Oncol. 2005, 16, 389-396. [CrossRef]

73. Regan, M.M.; Walley, B.A.; Francis, P.A.; Fleming, G.F.; Láng, I.; Gómez, H.L.; Colleoni, M.; Tondini, C.; Pinotti, G.; Salim, M.; et al. Concurrent and Sequential Initiation of Ovarian Function Suppression with Chemotherapy in Premenopausal Women with Endocrine-Responsive Early Breast Cancer: An Exploratory Analysis of TEXT and SOFT. Ann. Oncol. 2017, 28, $2225-2232$. [CrossRef] [PubMed]

74. Cardoso, F.; Senkus, E.; Costa, A.; Papadopoulos, E.; Aapro, M.; André, F.; Harbeck, N.; Aguilar Lopez, B.; Barrios, C.H.; Bergh, J.; et al. 4th ESO-ESMO International Consensus Guidelines for Advanced Breast Cancer (ABC 4). Ann. Oncol. 2018, 29, 1634-1657. [CrossRef]

75. Giuseppe, L.; Attilio, G.; Edoardo, D.N.; Loredana, G.; Cristina, L.; Vincenzo, L. Ovarian Function after Cancer Treatment in Young Women Affected by Hodgkin Disease (HD). Hematol. Amst. Neth. 2007, 12, 141-147. [CrossRef]

76. Behringer, K.; Wildt, L.; Mueller, H.; Mattle, V.; Ganitis, P.; van den Hoonaard, B.; Ott, H.W.; Hofer, S.; Pluetschow, A.; Diehl, V.; et al. No Protection of the Ovarian Follicle Pool with the Use of GnRH-Analogues or Oral Contraceptives in Young Women Treated with Escalated BEACOPP for Advanced-Stage Hodgkin Lymphoma: Final Results of a Phase II Trial from the German Hodgkin Study Group. Ann. Oncol. 2010, 21, 2052-2060. [CrossRef]

77. Demeestere, I.; Brice, P.; Peccatori, F.A.; Kentos, A.; Gaillard, I.; Zachee, P.; Casasnovas, R.-O.; Van Den Neste, E.; Dechene, J.; De Maertelaer, V.; et al. Gonadotropin-Releasing Hormone Agonist for the Prevention of Chemotherapy-Induced Ovarian Failure in Patients with Lymphoma: 1-Year Follow-up of a Prospective Randomized Trial. J. Clin. Oncol. 2013, 31, 903-909. [CrossRef] [PubMed]

78. Demeestere, I.; Brice, P.; Peccatori, F.A.; Kentos, A.; Dupuis, J.; Zachee, P.; Casasnovas, O.; Van Den Neste, E.; Dechene, J.; De Maertelaer, V.; et al. No Evidence for the Benefit of Gonadotropin-Releasing Hormone Agonist in Preserving Ovarian Function and Fertility in Lymphoma Survivors Treated with Chemotherapy: Final Long-Term Report of a Prospective Randomized Trial. J. Clin. Oncol. 2016, 34, 2568-2574. [CrossRef]

79. Yang, B.; Shi, W.; Yang, J.; Liu, H.; Zhao, H.; Li, X.; Jiao, S. Concurrent Treatment with Gonadotropin-Releasing Hormone Agonists for Chemotherapy-Induced Ovarian Damage in Premenopausal Women with Breast Cancer: A Meta-Analysis of Randomized Controlled Trials. Breast 2013, 22, 150-157. [CrossRef] 
80. Wang, C.; Chen, M.; Fu, F.; Huang, M. Gonadotropin-Releasing Hormone Analog Cotreatment for the Preservation of Ovarian Function during Gonadotoxic Chemotherapy for Breast Cancer: A Meta-Analysis. PLoS ONE 2013, 8, e66360. [CrossRef] [PubMed]

81. Vitek, W.S.; Shayne, M.; Hoeger, K.; Han, Y.; Messing, S.; Fung, C. Gonadotropin-Releasing Hormone Agonists for the Preservation of Ovarian Function among Women with Breast Cancer Who Did Not Use Tamoxifen after Chemotherapy: A Systematic Review and Meta-Analysis. Fertil. Steril. 2014, 102, 808-815.e1. [CrossRef] [PubMed]

82. Shen, Y.-W.; Zhang, X.-M.; Lv, M.; Chen, L.; Qin, T.-J.; Wang, F.; Yang, J.; Liu, P.-J.; Yang, J. Utility of Gonadotropin-Releasing Hormone Agonists for Prevention of Chemotherapy-Induced Ovarian Damage in Premenopausal Women with Breast Cancer: A Systematic Review and Meta-Analysis. OncoTargets Ther. 2015, 8, 3349-3359. [CrossRef] [PubMed]

83. Lambertini, M.; Ceppi, M.; Poggio, F.; Peccatori, F.A.; Azim, H.A.; Ugolini, D.; Pronzato, P.; Loibl, S.; Moore, H.C.F.; Partridge, A.H.; et al. Ovarian Suppression Using Luteinizing Hormone-Releasing Hormone Agonists during Chemotherapy to Preserve Ovarian Function and Fertility of Breast Cancer Patients: A Meta-Analysis of Randomized Studies. Ann. Oncol. 2015, 26, 2408-2419. [CrossRef] [PubMed]

84. Munhoz, R.R.; Pereira, A.A.L.; Sasse, A.D.; Hoff, P.M.; Traina, T.A.; Hudis, C.A.; Marques, R.J. Gonadotropin-Releasing Hormone Agonists for Ovarian Function Preservation in Premenopausal Women Undergoing Chemotherapy for Early-Stage Breast Cancer: A Systematic Review and Meta-Analysis. JAMA Oncol. 2016, 2, 65-73. [CrossRef]

85. Silva, C.; Caramelo, O.; Almeida-Santos, T.; Ribeiro Rama, A.C. Factors Associated with Ovarian Function Recovery after Chemotherapy for Breast Cancer: A Systematic Review and Meta-Analysis. Hum. Reprod. 2016, 31, 2737-2749. [CrossRef]

86. Bai, F.; Lu, Y.; Wu, K.; Chen, Q.; Ding, L.; Ge, M.; Weng, Z. Protecting Effects of Gonadotropin-Releasing Hormone Agonist on Chemotherapy-Induced Ovarian Damage in Premenopausal Breast Cancer Patients: A Systematic Review and Meta-Analysis. Breast Care 2017, 12, 48-52. [CrossRef] [PubMed]

87. Lambertini, M.; Moore, H.C.F.; Leonard, R.C.F.; Loibl, S.; Munster, P.; Bruzzone, M.; Boni, L.; Unger, J.M.; Anderson, R.A.; Mehta, K.; et al. Gonadotropin-Releasing Hormone Agonists During Chemotherapy for Preservation of Ovarian Function and Fertility in Premenopausal Patients with Early Breast Cancer: A Systematic Review and Meta-Analysis of Individual Patient-Level Data. J. Clin. Oncol. 2018, 36, 1981-1990. [CrossRef]

88. Lambertini, M.; Boni, L.; Michelotti, A.; Gamucci, T.; Olmeo, N.; Gori, S.; Giordano, M.; Garrone, O.; Levaggi, A.; Poggio, F.; et al. Long-Term Outcome Results of the Phase III PROMISE-GIM6 Study Evaluating the Role of LHRH Analog (LHRHa) during Chemotherapy (CT) as a Strategy to Reduce Ovarian Failure in Early Breast Cancer (BC) Patients. J. Clin. Oncol. 2014, 32, 105. [CrossRef]

89. Waxman, J.H.; Ahmed, R.; Smith, D.; Wrigley, P.F.; Gregory, W.; Shalet, S.; Crowther, D.; Rees, L.H.; Besser, G.M.; Malpas, J.S. Failure to Preserve Fertility in Patients with Hodgkin's Disease. Cancer Chemother. Pharmacol. 1987, 19, 159-162. [CrossRef]

90. Gilani, M.M.; Hasanzadeh, M.; Ghaemmaghami, F.; Ramazanzadeh, F. Ovarian Preservation with Gonadotropin-Releasing Hormone Analog during Chemotherapy. Asia Pac. J. Clin. Oncol. 2007, 3, 79-83. [CrossRef]

91. Lawrenz, B.; Fehm, T.; von Wolff, M.; Soekler, M.; Huebner, S.; Henes, J.; Henes, M. Reduced Pretreatment Ovarian Reserve in Premenopausal Female Patients with Hodgkin Lymphoma or Non-Hodgkin-Lymphoma-Evaluation by Using Antimüllerian Hormone and Retrieved Oocytes. Fertil. Steril. 2012, 98, 141-144. [CrossRef] [PubMed]

92. Lekovich, J.; Lobel, A.L.S.; Stewart, J.D.; Pereira, N.; Kligman, I.; Rosenwaks, Z. Female Patients with Lymphoma Demonstrate Diminished Ovarian Reserve Even before Initiation of Chemotherapy When Compared with Healthy Controls and Patients with Other Malignancies. J. Assist. Reprod. Genet. 2016, 33, 657-662. [CrossRef] [PubMed]

93. Clowse, M.E.B.; Behera, M.A.; Anders, C.K.; Copland, S.; Coffman, C.J.; Leppert, P.C.; Bastian, L.A. Ovarian Preservation by GnRH Agonists during Chemotherapy: A Meta-Analysis. J. Women's Health 2009, 18, 311-319. [CrossRef] [PubMed]

94. Ben-Aharon, I.; Gafter-Gvili, A.; Leibovici, L.; Stemmer, S.M. Pharmacological Interventions for Fertility Preservation during Chemotherapy: A Systematic Review and Meta-Analysis. Breast Cancer Res. Treat. 2010, 122, 803-811. [CrossRef]

95. Kim, S.S.; Lee, J.R.; Jee, B.C.; Suh, C.S.; Kim, S.H.; Ting, A.; Petroff, B. Use of Hormonal Protection for Chemotherapy-Induced Gonadotoxicity. Clin. Obstet. Gynecol. 2010, 53, 740-752. [CrossRef]

96. Bedaiwy, M.A.; Abou-Setta, A.M.; Desai, N.; Hurd, W.; Starks, D.; El-Nashar, S.A.; Al-Inany, H.G.; Falcone, T. GonadotropinReleasing Hormone Analog Cotreatment for Preservation of Ovarian Function during Gonadotoxic Chemotherapy: A Systematic Review and Meta-Analysis. Fertil. Steril. 2011, 95, 906-914.e4. [CrossRef] [PubMed]

97. Zhang, Y.; Xiao, Z.; Wang, Y.; Luo, S.; Li, X.; Li, S. Gonadotropin-Releasing Hormone for Preservation of Ovarian Function during Chemotherapy in Lymphoma Patients of Reproductive Age: A Summary Based on 434 Patients. PLoS ONE 2013, 8, e80444. [CrossRef]

98. Sun, X.; Dongol, S.; Jiang, J.; Kong, B. Protection of Ovarian Function by GnRH Agonists during Chemotherapy: A Meta-Analysis. Int. J. Oncol. 2014, 44, 1335-1340. [CrossRef]

99. Del Mastro, L.; Ceppi, M.; Poggio, F.; Bighin, C.; Peccatori, F.; Demeestere, I.; Levaggi, A.; Giraudi, S.; Lambertini, M.; D’Alonzo, A.; et al. Gonadotropin-Releasing Hormone Analogues for the Prevention of Chemotherapy-Induced Premature Ovarian Failure in Cancer Women: Systematic Review and Meta-Analysis of Randomized Trials. Cancer Treat. Rev. 2014, 40, 675-683. [CrossRef]

100. Senra, J.C.; Roque, M.; Talim, M.C.T.; Reis, F.M.; Tavares, R.L.C. Gonadotropin-Releasing Hormone Agonists for Ovarian Protection during Cancer Chemotherapy: Systematic Review and Meta-Analysis. Ultrasound Obstet. Gynecol. 2018, 51, 77-86. [CrossRef] 
101. Hickman, L.C.; Llarena, N.C.; Valentine, L.N.; Liu, X.; Falcone, T. Preservation of Gonadal Function in Women Undergoing Chemotherapy: A Systematic Review and Meta-Analysis of the Potential Role for Gonadotropin-Releasing Hormone Agonists. J. Assist. Reprod. Genet. 2018, 35, 571-581. [CrossRef]

102. Sofiyeva, N.; Siepmann, T.; Barlinn, K.; Seli, E.; Ata, B. Gonadotropin-Releasing Hormone Analogs for Gonadal Protection During Gonadotoxic Chemotherapy: A Systematic Review and Meta-Analysis. Reprod. Sci. 2019, 26, 939-953. [CrossRef] [PubMed]

103. Zheng, F.; Zhu, B.; Feng, Q.; Wu, L.; Cui, Y.; Liu, Y.; Wang, Y. Protective Effect of Gonadotropin-Releasing Hormone Agonist against Chemotherapy-Induced Ovarian Dysfunction: A Meta-Analysis. Oncol. Lett. 2019, 17, 5319-5326. [CrossRef] [PubMed]

104. Chen, H.; Xiao, L.; Li, J.; Cui, L.; Huang, W. Adjuvant Gonadotropin-Releasing Hormone Analogues for the Prevention of Chemotherapy-Induced Premature Ovarian Failure in Premenopausal Women. Cochrane Database Syst. Rev. 2019,3 , CD008018. [CrossRef]

105. Luong, S.-N.; Isaacs, A.; Liu, Z.; Sin, F.E.; Giles, I. A Systematic Review and Meta-Analysis of the Gonadotoxic Effects of Cyclophosphamide and Benefits of Gonadotropin Releasing Hormone Agonists (GnRHa) in Women of Child-Bearing Age with Autoimmune Rheumatic Disease. Expert Rev. Clin. Immunol. 2020, 16, 321-333. [CrossRef] [PubMed]

106. Lambertini, M.; Blondeaux, E.; Bruzzone, M.; Perachino, M.; Anderson, R.A.; de Azambuja, E.; Poorvu, P.D.; Kim, H.J.; Villarreal-Garza, C.; Pistilli, B.; et al. Pregnancy after Breast Cancer: A Systematic Review and Meta-Analysis. J. Clin. Oncol. 2021, JCO.21.00535. [CrossRef]

107. Franzoi, M.A.; Agostinetto, E.; Perachino, M.; Del Mastro, L.; de Azambuja, E.; Vaz-Luis, I.; Partridge, A.H.; Lambertini, M. Evidence-Based Approaches for the Management of Side-Effects of Adjuvant Endocrine Therapy in Patients with Breast Cancer. Lancet Oncol. 2021, 22, e303-e313. [CrossRef] 